DOI: https://doi.org/10.31933/dijdbm.v2i3

Received: 29 March 2021, Revised: 10 April 2021, Publish: 30 April 2021

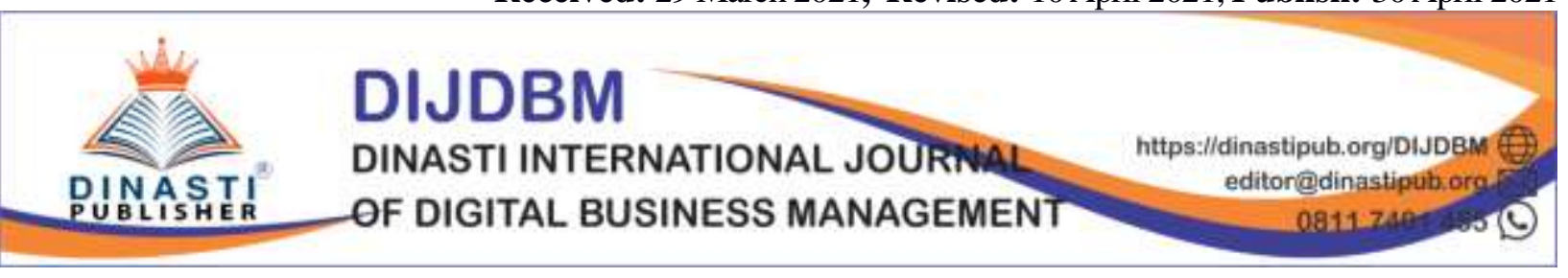

\title{
CUSTOMER SATISFACTION DETERMINATION AND IMPLICATIONS ON BEHAVIOR INTENTION (EMPIRICAL STUDY OF FOUR AND FIVE STAR HOTELS IN NORTH SULAWESI)
}

\section{Elim Noldy Paendong}

Persada Indonesia University YAI, Indonesia, elimpaendong@gmail.com

\section{Corresponding Author: First Author ${ }^{1}$}

\begin{abstract}
This study aims to determine and empirically prove the positive relationship between servicescape, interaction orientation, service convenience on customer satisfaction, and implications for behavior intention. This research problem departs from the concept of pentahelix in the tourism industry and the Ministry of Tourism's priority programs, especially digital tourism, and homestays are the central themes in this research. The success of achieving the target of tourist visits is closely related to the accommodation system at the destination, in this case the role of the hotel. On the other hand, the sustainability of a destination is closely related to the operations of the hotels located in that destination. That is, in conditions of an increase in the flow of visits to certain destinations accompanied by a rapid increase in the number of hotels. So it can be concluded that in a business both goods and services, servicescape, Interaction Orientation, Service Convenience are important factors in increasing customer satisfaction, even the three tadit factors, namely servicescape, interaction orientation, service convenience can encourage customer interest in using the product or services offered.
\end{abstract}

Keyword: customer satisfaction, service convenience, servicescape.

\section{INTRODUCTION}

This research problem departs from the concept of pentahelix in the tourism industry and the Ministry of Tourism's priority programs, especially digital tourism, and homestays are the central themes in this research. First, regarding the homestay program related to accommodation functions such as hotels. The success of achieving the target of tourist visits is closely related to the accommodation system at the destination, in this case the role of the hotel. On the other hand, the sustainability of a destination is closely related to the operations of the hotels located in that destination. That is, in conditions of an increase in the flow of visits to certain destinations coupled with a rapid increase in the number of hotels, of course, you must also pay attention to the physical aspects of the hotel, the service of its employees, and the atmosphere of comfort for tourists visiting certain destinations, but if these conditions, the hotel cannot provide guarantees, 
it will cause problems regarding the sustainability of these destinations. "Therefore, fast growth of the hotel industry has an ability to create another problem for the sustainability of the destination. (Sandaruwani \& C., 2016)

The operational sustainability of a destination is highly dependent on the existence of accommodation, such as hotels which must be supported by the availability of physical facilities, the presence of employees, and the convenience of services. Generally provided through hotel facilities, but in reality hotel operations do not reach all existing destinations, and / or the acceleration of destination growth is not as fast as hotel growth. Therefore, one solution is the existence of a homestay. On the one hand, the existence of a homestay is also an alternative, when the hotel does not provide satisfactory service according to the expectations of tourists as hotel guests. Therefore, it is very important to examine the relationship between satisfaction and hotel consumer behavior.

Second, the relationship between satisfaction and hotel consumer behavior is determined by 3 main factors, namely the physical environment, the non-physical environment, and the situational environment. The physical environment is an artificial environment in the marketing literature called servicescape, and the non-physical environment is the personal interaction relationship between employees on behalf of hotel management and consumers. Meanwhile, the hotel situation is a condition where services are provided by service providers to service recipients who are consumers as hotel guests. Research by (Kasa et al., 2019) explains that the hotel industry requires support for a pleasant service climate, which in essence can be provided by hotel employees so that consumers are satisfied."Thus, the hotel industry needs to be supported toward service climate; as referred to when the hotels' focal point is the degree to which employees main concentration is directed toward rendering service quality and customer satisfaction (Kasa et al., 2019)

Third, it is important to pay attention to the physical environment of the hotel because it is also the environment where hotel employees work. "There are important factors in the employee's workplace that influence significantly on their level of motivation and performance. The main objective of the study is to understand the relationship between theemployees' performance and their physical work environment (El-Zeiny, 2012). In a highly competitive business environment, companies cannot ignore the potential that can be obtained from the work environment where employees work. The workplace is an important factor that has a significant influence on the level of performance and employee motivation. Theoretically, it is stated that a good office design has a positive effect on employee productivity. "In today's competitive business environment, corporations can no longer afford to waste the potential of their workforce. There are important factors in the employee's workplace that significant influencey on their level of motivation and performance. The literature reveals that good office design has a positive effect on employees' productivity (El-Zeiny, 2012).

Fourth, based on observations, it shows that a technical portrait of the performance of the hotel business is currently faced with several things, including: the appearance of star hotels which still lacks appeal because it is rarely or not changed at all, and even the decoration is meaningless. This condition is related to the servicescape aspect, which allows the hotel to design a service environment and work environment as attractive as possible so that guests feel comfortable and employees can provide maximum service. 
Fifth, the fact is that promotion of hotel services is more oriented towards foreign tourists. In order for promotional policies to have an impact on all target markets, servicescape is a solution in the form of brochures or leaflets and various other promotional media that are designed proportionally for domestic and foreign market segments. In essence, servicescape is very useful for hotel management in implementing promotional policies.

Fifth, the friendliness and politeness of the hotel maids needs to be improved. Observations show that when guests are having breakfast, the waiter displays a face that is less friendly or less friendly. The way the waiter asks guests how many people are going to eat breakfast, how many adults and how many children, and counts them in front of other guests. Individual services during breakfast at hotels that are not yet optimal, for example visiting guests who are having breakfast and offering coffee or tea. Hotel restaurant tables that are not quickly cleaned and tidied up after being used by guests at breakfast, for use by other guests.

In addition, there is a lack of relationships between customers and hotels, for example a customer database in the hotel industry that contains names, addresses, occupations, destination of lodging, and other preferences such as room type, food ordered, and when they last stayed at the hotel. This is valuable information for building relationships. Likewise with the waiting time for check in and check out, it still takes time to wait when checking in and checking out, waiting time for telephone answers is a bit long, internet, fax access is a bit slow, and waiting time for bellboys is rather long, and there are still costs. consumer interactions with hotel services, for example, hotel maids have not been able to refuse tipping by guests when guests request services from the hotel.

These problem conditions are closely related to the interaction quality of hotel employees in various tasks and functions, ranging from cleaning services, drivers, doormans, bellboys, roomboys, waiters, to employees who serve as receptionists and cashiers. The interaction of employees with guests facilitates the process of service transactions being given and received well, which in the end the guests feel satisfied, and want to come back in the future.

Sixth, the lack of superior value creation to consumers such as agile employees, for example: not all hotels have wellcome drinks, loyalty programs, special discounts for customers. When told there is a shortage or damage, you must respond quickly. Friendly and attentive maids, cleaning the room must be on the phone first or put a notice at the door. There are still hotels that do not yet provide smoking rooms for visitors, in the hotel lobby or in the hotel restaurant. Lack of comfortable bed, sleeping pillows that are a bit old, the smell of the room is less pleasant.

There is still a lack of attention to the needs of its customers, such as offering services to get services quickly at hotels where you stay, for example, there are city tour programs, the availability of car rentals that don't wait long. The low level of customer confidence in the sense of security and comfort for hotel employees with the valuable items deposited by customers. Information delivery to customers is still low, such as a map of the location of important places around the hotel that must be conveyed to customers. The condition of this problem is related to the concept of service maintenance and customer satisfaction, which allows hotel guests to get all the pleasant services that exceed their expectations. 
Based on such opinions, it is very important to examine the service environment in which the service is provided, as well as the environment in which employees work, including interactions between employee and employees, and especially between employees and customers. In the service business, as in the hotel industry, apart from the service environment, the comfort and interaction skills of employees also play an important role to be researched, so that guests feel satisfied and have the desire to return in the future.

\section{LITERATURE REVIEW Servicescape}

(Kumar et al., 2017) defines servicescape (service environment) as the style and appearance of the physical surrounding and other experiential elements encountered by customer at service delivery site. That is, servicescape or service environment as the style and appearance of the physical environment around it and the elements of experience that consumers receive or feel for the services provided. This definition emphasizes two aspects of the servicescape, namely the physical environment and experience. In the eyes of consumers, these two things are related to one another.

(Raza, 2013) explain arguments for the importance of servicescape, among others; servicescape wraps services and forms an external image of what is inside the company to the customer. Servicescape is the outward appearance of the organization and is therefore very important in shaping the first impression or shaping customer expectations. Servicescape can also be a facilitator in increasing customer satisfaction. Good design and functional facilities can make services more enjoyable for customers to experience. Conversely, bad and inefficient designs will frustrate customers. In addition, servicescape as a socializer that servicescape design can state what their role is, in what parts of the servicescape they are welcomed,

\section{Interaction Quality}

The quality of interaction is a quality that is closely related to how the service process is delivered starting from the interaction process of service providers with their customers and the interaction process can be seen from how staff behave, behave towards their customers and their expertise (Nunkoo et al., 2020). According to (Tjiptono \& Chandra, 2011) the dimensions of interaction quality include the attitudes, behavior and expertise of service provider employees. The three interaction models are seen from the importance of attitude, behavior and expertise in providing the main and best service. In developing the quality of interaction in a marketing product, every marketing developer is required to have the ability to interact with attitudes, behavioral interaction skills and interaction skills. Attitude interactions, identical with how to disclose something in accordance with the perception or assumption about the product or service chosen or used. Behavior is identical to how to act in carrying out an activity from the purchase or sale of a selected product or service. Interaction skills are identical to the perspective and way of acting which are combined in knowing correctly about the subject and object of the product or service chosen.

\section{Service Convenience}

According to (Raza, 2013) service convenience is the consumer's perception of the ease of time and effort associated with purchasing or using a service. Time and effort are two important aspects that affect service convenience. It is said that there are five types, service convenience, namely decision convenience, access convenience, transaction convenience, 
benefits convenience, and post benefit convenience. These five types of service convenience describe the stages of consumer activity related to purchasing or using services, time and effort related to types of services that affect convenience. Consumers as a whole towards evaluating service convenience.

Furthermore, Dyah Lestari Widaningruma (2015) in his research stated that the factors as the main attributes of a convenience store, namely: public points (ATMs, bus stations, fuel, parking, stations, town halls), health facilities (clinic, dentist, hospital, pharmacy), office (bank, commercial, fire station, office of police, post office), leisure (attravtion, bar, boundary stone, cinema, hostel, hotel, monument, motel, nightclub, pitch, sport center) education (kindergarten, scholl, university), footfall (bakery, convenience, fast food, green grocer, hairdresser, mall, residential, restaurant, supermarket).

\section{Customer Satisfaction}

(Kaura et al., 2015) state that customer satisfaction is the customer's response to the perceived evaluation between previous expectations and the actual performance of the product after its use. Customer satisfaction is a function of expectations and performance. (Nunkoo et al., 2020) identify customer satisfaction as an after-purchase evaluation of the chosen alternatives that give the same results or exceed customer expectations. Dissatisfaction arises when the results obtained do not meet customer expectations. (El-Adly, 2019) argues that customer satisfaction is the level of a person's feelings after comparing perceived performance against expectations. Satisfaction is a feeling of pleasure or disappointment that a person has based on a comparison of his impression of the results of a product with the expectations he has (El-Adly, 2019). This can also be interpreted as a after-purchase evaluation where the results received are the same as expected or exceed consumer expectations, while dissatisfaction arises if the results do not meet the expectations of the consumer (Priyo et al., 2019).

\section{Behavior Intention}

Consumers in the act of buying and using a product are not only influenced by themselves but also subject to subjective norms. According to in Ronny Juwana (2013, p. 6) "Subjective norm is the person's perception that most people who are important to him think he should or should not perform the behavior in question". According to Schiffman and Kanuk (2007) in Ronny Juwana (2013, p.6) (defining subjective norms is consumer perceptions of what other people want consumers to do certain behaviors. The main normative beliefs of consumers are related to "doing what other people want them to do. do "and motivation to meet the expectations of others is communicated to form subjective norms. According to Peter and Olson (2010) Ronny Juwana (2013, p.6) subjective norm about the behavior is formed by two components, namely belief in other people (reference or reference group) and motivation. Behavior intention is certain behavior towards a product or service that is consumed by consumers.

When interacting with consumers, the company must carefully observe the behavioral interest that consumers have if the business entity does not want to lose consumers. By studying the behavioral interests that consumers have, business entities can see signs of whether consumers still wish to stay in touch with the business entity. As stated by Ajzen (1991) in Ronny Juwana (2013, p.6), defines behavioral intention "... representations of people's plans of action and summarize people's motivation to engage in the behavior, thus the more motivated people 
are to engage in the behavior, the more likely will be its successful performance ". Behavioral intention is a representation of one's plan of action and a summary of one's motivation to engage in a behavior. Therefore,

\section{DISCUSSION}

In short, this research problem departs from kThe pentahelix concept in the tourism industry and the Ministry of Tourism's priority programs, particularly digital tourism and homestays, are the central themes in this research. First, regarding homestay programs related to accommodation functions such as hotels. The success of achieving the target of border visits is closely related to the accommodation system at the destination destination. Generally provided through hotel facilities, but in reality hotel operations do not reach all existing destinations, and / or the acceleration of destination growth is not as fast as hotel growth. Therefore, one solution is the existence of a homestay. On the one hand, the existence of a homestay is also an alternative, when the hotel does not provide satisfactory service according to the expectations of tourists as hotel guests. Therefore,

Second, the relationship between satisfaction and hotel consumer behavior is determined by 3 main factors, namely the physical environment, the non-physical environment, and the situational environment. The physical environment is an artificial environment in the marketing literature called servicescape, and the non-physical environment is the personal interaction relationship between employees on behalf of hotel management and consumers. Meanwhile, the hotel situation is a condition where services are provided by service providers to service recipients who are consumers as hotel guests.

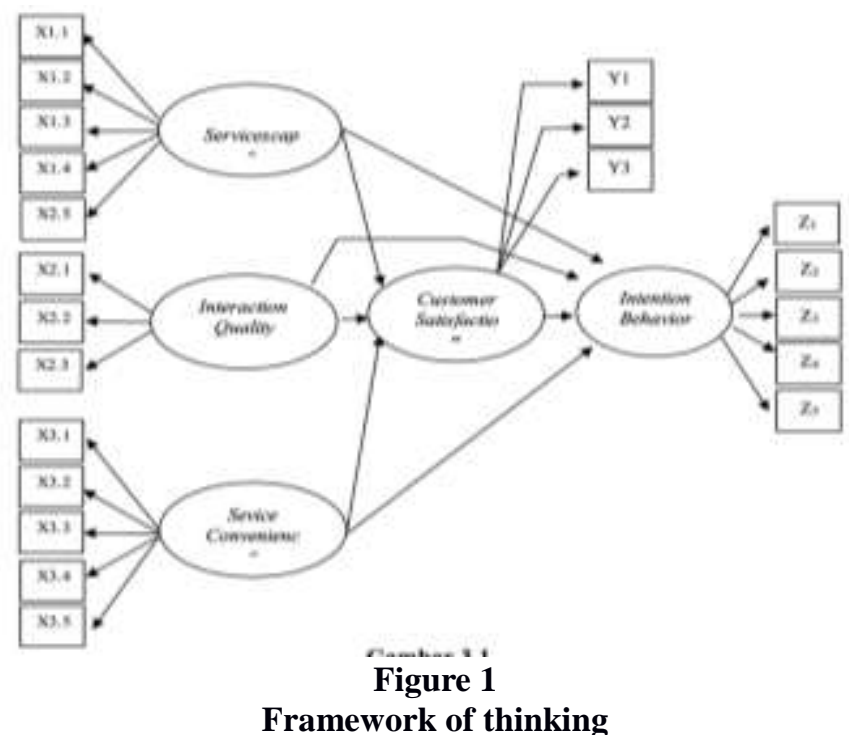

\section{Servicescape and Customer Satisfaction}

Physical environment, customer satisfaction, and perceived quality affect the length of time consumers shop and spend time receiving services. "Physical environment, customers' 
satisfaction, and perceived quality affected by the length of time that customers spend inside the service setting" (Norhidayah Mohd Rashida et al., 2015). Likewise, several previous studies (Bitner 1990; Harrell, Hut, and Anderson 1980) concluded that the design of the physical environment affects customer satisfaction through service, productivity, and motivation (Suhaila Sufara et al., 2010).

Norhidayah Mohd Rashida et al. (2015) in his research usingambient condition, spatial layout / functionality, and signs, symbols, and artifacts, as determining factors for customer satisfaction. "The three dimensions of servicescape used in this study as a yardstick to measure an exhibitors' satisfaction consist of ambient condition, spatial layout / functionality and sign, symbols, artifacts".

Furthermore, in relation to hotel research objects, Yangyang Gao's research (2016) seeks to explain that the overall satisfaction of hotel guests is through structuring the environmental attributes of the service room for guests. In his research concluded that "cleanliness of bed linen, the cleanliness of other details in the guest room, and" the sound insulation of the guest room "have a significant effect on the overall satisfaction of guests, and this is the answer why guests are in the guest room. the hotel.

\section{Interaction Quality and Customer Satisfaction}

Prabu Wardono, et al., (2012) in their research on restaurant objects explained that the perceptions, emotions, and behavior of consumers are important socio-psychological factors in determining the satisfaction of their eating experiences. Perceptions, emotions, and consumer behavior represent socio-psychological factors which are important for determining their experience when eating at the restaurant. Although it cannot be explained in detail, how the service environment should be prepared for the success of goals in the context of social eating intention can be achieved.

The idea of a concept interaction orientation first developed by Kumar and Ramani in 2006 who argue:

"The idea of interaction orientation was first developed by Kumar and Ramani (2006), who stated that it reflects a firm's ability to interact with its individual customers and to take advantage of the information obtained from them through successive interactions in order to achieve profitable customer relationships

(in Rong-Da Liang, and Jun-Shu Zhang, 2011)

Interaction orientationreflects the company's ability to interact with consumers individually and aims to achieve superior information obtained through interactions within the framework of a profitable customer relationship. Rong-Da Liang, and Jun-Shu Zhang (2011) defined interaction orientation as a representation of a restaurant's ability to interact with individuals at dinner and obtain information from efforts to maintain long-term and mutually beneficial relationships with consumers. Interaction orientation is measured by 4 main elements, namely: the concept of the customer; interaction response capacity; customer empowerment; and customer value management (Rong-Da Liang, and Jun-Shu Zhang, 2011). 
Interaction orientationleads to increased customer satisfaction. In this study, it is shown that empowering consumers individually by developing unique experiences from consumers will increase their satisfaction (Rong-Da Liang, and Jun-Shu Zhang, 2011). The superior interaction orientation results in the peak of maximum customer satisfaction. This means that the restaurant's efforts to develop and improve interaction orientation will reach the peak of customer satisfaction (Rong-Da Liang, and Jun-Shu Zhang, 2011).

This explanation is in line with the writing of Gina A. Tran (2014) in her dissertation that "marketers use the interactive opportunities of electronic communications to aid their viral marketing campaign efforts. "Employing interactivity as part of viral marketing gives companies the chance to better understand consumers, which can lead to more strategic marketing to gain customers in the target market segments". "Consumers also benefit from interactive campaigns because they can express their thoughts and opinions. There is also the potential for consumers to be active co-producers when new product ideas are presented for sweepstakes and contests "; "Involving consumers in the product development process generates excitement and publicity for the company".

\section{Service Convenience and Customer Satisfaction}

Norhidayah Mohd Rashida et al., (2015) explained that the convenience of consumers in accessing a required service facility will increase the frequency of use by customers, in this case exhibitors. For this reason, the essence of venue operators is to maintain the facilities provided in good condition, because in such conditions it is related to satisfaction and leads to efforts to maintain customers (the customers's retention).

\section{Servicescape, Interaction Orientation, Service Convenience, Customer Satisfaction Satisfaction}

There is a relationship between interaction orientation, customer satisfaction and loyalty (Namkung and Jang, 2009). Meanwhile, the relationship between convenience based on good experiences from customers with satisfaction and loyalty, as a consequence, consumers become loyal or feel satisfied because they experience good service (Rong-Da Liang, and Jun-Shu Zhang, 2011).

Furthermore, research by Rong-Da Liang and Jun-Shu Zhang (2011) explains that technological developments and an increase in the intensity of interactions between companies and customers will increase the suitability of demand for products and services with their offerings. Experts agree that an interaction orientation will enable businesses to be able to increase their knowledge of consumer wants and tastes. Interaction orientation can increase consumer satisfaction and strengthen repurchase behavior and lead to consumer confidence in the company. The consequences of individual interactions and relationships will result in efficiency and effectiveness in management which are ultimately recognized as a source of competitive advantage (Rong-Da Liang, and Jun-Shu Zhang, 2011).

Several previous studies examined how interaction orientation can affect consumer satisfaction and loyalty, and even in the future according to Ramani and Kumar in their research, the 2008 interaction orientation will have an impact on consumer satisfaction and their desire to behave (loyal) between companies in the service industry (Rong-Da Liang, and Jun-Shu Zhang, 2011). 


\section{Servicescape and Behavior Intention}

Likewise, several previous studies (Bitner, MJ, 1992) added the conclusion that human behavior is influenced by the design of the physical environment and the interior of the environment (in Suhaila Sufara et al., 2010).

"According to Darly and Gilbert 1985; Holahan 1986; Russell and Ward 1982; Stokols and Altman 1987) in Bitner, MJ (1992), add that human behavior is influenced by the physical setting and interior environment in which occurs is essentially a truism ".

(in Suhaila Sufara et al., 2010)

In the field of environmental psychology research (environmental psychology) places the relationship between human existence and the artificial environment. The assumption is that the dimensions of the organization's physical environment affect employee and consumer behavior (Suhaila Sufara et al., 2010).

"Interestingly, the field of environmental psychology has addressed the relationship between human beings and their built environment. Here, it is assumed that dimensions of the organization's physical surroundings influence important customer and employee behaviors. ".

(Suhaila Sufara et al., 2010)

Basically, hotel managers can use several choices of servicescape elements in increasing visits or influencing guests to come back and recommend through fun stories to others. The data shows that the servicescape received by guests positively affects customer value, return visits, and word of mouth to others.

"Hotel managers could choose either to change lighting temperature or to change complexity level to generate high perceived servicescape and / or perceived value, which increases guests' intention to revisit and intention to spread positive word-of-mouth ".

"Finally, the data showed that perceived services were positively influenced by perceived value, intention to revisit, and intention to spread positive word-of-mouth. Perceived value positively influenced intention to revisit and intention to spread positive word-of-mouth".

(Jing Yang, 2015)

Academically, servicescape influencing consumer behavior, as a determinant of behavior intentions, such as word-of-mouth or repurchase intention (Bitner, 1992). "... servicescape as a 
determinant of behavioral intentions, such as word-of-mouth or repurchase intention" (Jing Yang, 2015), and "intention to repatronize" (Wakefield and Blodgett, 1996).

\section{Interaction Quality and Behavior Intention}

Nurhazirah Hashima's (2015) research regarding the decision to buy a house by taking into account demographic factors in Malaysia explains that social interaction and satisfaction with neighbors determine their decision to buy a house.

Behavioral intentionsincludes recommendations to others, convey positive things about the company by word of mouth, and the desire to be part of the partnership, and willingness to be loyal to the company (Rong-Da Liang, and Jun-Shu Zhang, 2011). Such consumers besides believing that the company provides superior value, they also feel the goodness of their relationship with the company (Rong-Da Liang, and Jun-Shu Zhang, 2011).

Companies develop interaction-oriented services (such as the ability to respond to interactions) to better plan marketing activities and maintain mutually beneficial long-term customer relationships, for example increasing loyalty (Rong-Da Liang, and Jun-Shu Zhang,2011). Interaction orientation increases positive word of mouth and encourages consumers to refer companies to new potential customers, and / or vice versa. Therefore, an interaction orientation is specific and tangible, and can be adopted by companies to achieve superior performance success through customer loyalty (Rong-Da Liang, and Jun-Shu Zhang, 2011).

Rong-Da Liang, and Jun-Shu Zhang (2011) in his research concluded that interaction orientation is related to behavioral intentions. The high level of interaction in a quality service process in a restaurant will show the strong desire to behave from consumers or recommend word of mouth about the restaurant.

\section{Service Convenience and Behavior Intention}

Norhidayah Mohd Rashida et al., (2015) explained that the convenience of consumers in accessing a required service facility will increase the frequency of use by customers, in this case exhibitors. For this reason, companies are required to maintain service facilities to keep them in good condition, because they relate to satisfaction and lead to the desire of consumers to survive (customers' retention).

Layout designs that are convenient in access for each consumer facility will increase perceptions and increase the percentage of consumers to return to using these service facilities. Comfortable layouts are positively related to consumer emotions (in Norhidayah Mohd Rashida, 2015).

\section{Customer Satisfaction and Behavior Intention}

Rong-Da Liang, and Jun-Shu Zhang (2011) in their research concluded that if consumers feel satisfied with restaurant services in the form of serving food, then they will tend to revisit the restaurant, and in the end the restaurant's profits will increase as well. Based on the study of the hospitality aspect, consumer satisfaction is important because it will affect the behavior of consumers to re-purchase because they are loyal to the service products they have received (Rong-Da Liang, and Jun-Shu Zhang, 2011). 
Olive in his research in 1999 also explained that customer satisfactionis also an important antasendent variable to behavioral intentions and actual behavior. Oliver believes that satisfaction leads to purchase or reuse and positive word of mouth recommendations as the main indicator of loyalty (Rong-Da Liang, and Jun-Shu Zhang, 2011).

The Hospitality Management literature discusses the relationship between customer satisfactionand loyalty finds a positive relationship with each other between the two concepts (Rong-Da Liang, and Jun-Shu Zhang, 2011). When consumers feel satisfied with the product / service, they will buy back, and are willing to talk about positive things by word of mouth to others.

Positive relationship between customer satisfaction and behavioral intentions, as evidenced by Oliver in his research in 1999 that high satisfaction will convincingly lead to consumers' desire to behave as before, such as WOM or repeat patronage (in Rong-Da Liang, and Jun-Shu Zhang, 2011). Customers who visit a restaurant for the first time will show their desire to return because they feel satisfied as part of their overall experience. $\mathrm{P}$ Managers consider how to increase satisfaction including local foods, a party atmosphere, excellent service as their strength to desire to return (Rong-Da Liang, and Jun-Shu Zhang, 2011).

\section{Servicescape, Interaction Quality, Service Convenience, Customer Satisfaction, and Behavior Intention}

Rong-Da Liang, and Jun-Shu Zhang (2011) in a study that aims to examine the relationship between interaction orientation, customer satisfaction and behavioral intention. The research results prove a significant relationship between interaction orientation to behavioral intention which is mediated by customer satisfaction.

Rong-Da Liang, and Jun-Shu Zhang (2011) in their research concluded that customer satisfaction mediates the relationship between interaction orientation and behavioral intention. Interaction orientation has a positive relationship with behavior intentions, and likewise with customer satisfaction has a positive relationship with behavior intention.

Namkung and Jang's 2009 study indicates there is an in-depth examination re-purchase frequency as a moderate role between service stimuli (such as value), customer affect (such as customer satisfaction) and response (such as customer loyalty). interaction orientation with customer satisfaction or behavioral intentions (in Rong-Da Liang, and Jun-Shu Zhang, 2011).

\section{CONCLUSION}

Based on the discussion above, from several studies it appears that there is a positive relationship between servicescape, Interaction Orientation, Service Convenience on customer satisfaction, and implications for behavior intention. The meaningin a business, both goods and services, servicescape, interaction orientation, service convenience are important factors in increasing customer satisfaction, even the three tadit factors, namely servicescape, interaction orientation, service convenience can encourage customer interest in using the product or service offered. This shows that satisfied customers will be motivated to repurchase the products or services offered to them.

\section{REFERENCE}


El-Adly, M. I. (2019). Modelling the relationship between hotel perceived value, customer satisfaction, and customer loyalty. Journal of Retailing and Consumer Services, 50. https://doi.org/10.1016/j.jretconser.2018.07.007

El-Zeiny, R. M. A. (2012). The Interior Design of Workplace and its Impact on Employees' Performance: A Case Study of the Private Sector Corporations in Egypt. Procedia - Social and Behavioral Sciences, 35. https://doi.org/10.1016/j.sbspro.2012.02.145

Kasa, M., Stephen, D., \& Hassan, Z. (2019). Rasch analysis and differential item functioning of work-related flow inventory (Wolf): A study on the hotel industry in Sarawak. Asia-Pacific Social Science Review, 19(3).

Kaura, Prasad, D., \& Sharma. (2015). Service quality, service convenience, price and fairness, customer loyalty, and the mediating role of customer satisfaction. International Journal of Bank Marketing, 33(4), 404-422. https://doi.org/10.1108/IJBM-04-2014-0048

Kumar, D. S., Purani, K., \& Sahadev, S. (2017). Visual service scape aesthetics and consumer response: a holistic model. Journal of Services Marketing, 31(6). https://doi.org/10.1108/JSM-01-2016-0021

Nunkoo, R., Teeroovengadum, V., Ringle, C. M., \& Sunnassee, V. (2020). Service quality and customer satisfaction: The moderating effects of hotel star rating. International Journal of Hospitality Management, 91. https://doi.org/10.1016/j.ijhm.2019.102414

Priyo, J. S., Mohamad, B., \& Adetunji, R. R. (2019). An examination of the effects of service quality and customer satisfaction on customer loyalty in the hotel industry. International Journal of Supply Chain Management, 8(1).

Raza, K. (2013). Impact of Servicescape on Customer Satisfaction. In International Journal of Economics (Vol. 1, Issue 1).

Sandaruwani, J. A. R. C., \& C., G. W. K. A. (2016). The role of tourist guides and their impacts on sustainable tourism development: A critique on Sri Lanka. Tourism, Leisure and Global Change, 3(July 2015).

Tjiptono, F., \& Chandra, G. (2011). Service, Quality \& Satisfaction. In Edisi 4.

So-Ra Jung, (2006). The perceived benefits of healthcare information construct and survey development. Thesis - B.S., Dankook University.

Suhaila Sufar, Anuar Talib, and Haris Hambali (2012). Towards a better Design: Physical Interior Environments of Public Libraries in Peninsular Malaysia. Procedia - Social and Behavioral Sciences. Vol. 42. pp. 131 - 143. ELSEFIER- Available online at www.sciencedirect.com.

Sugiyono. (2009). Metode Penelitian Bisnis. Cetakan Ketujuh, Alfabeta, Bandung - Indonesia.

Swan, J.E. and Oliver, R.L. (1989). "Postpurchase communications by consumers". Journal of Retailing. Vol. 65. pp. 516-33.

Tao Zhou (2013). An empirical examination of continuance intention of mobile payment services. Decision Support Systems. Vol. 54. pp. 1085-1091. ELSEFIER- Decision Support Systems. journal homepage: www.elsevier.com/locate/dss.

Tjiptono, F. (2007). Perspektif manajemen dan pemasaran kontemporer. Yogyakarta: Penerbit Andi. 
Tombs, Alastair., McColl-Kennedy, Janet R. (2002). Beyond the Servicescape: Customer to Customer Interactions in the Social Servicescape. ANZMAC Conference Proceedings.

Tomas G.M. Hult, (2001). Additional thoughts on international services marketing. Journal of Services Marketing. Vol. 15 (1). pp. 5-10.

Treasa Kearney, Joseph Coughlan, and Aileen Kennedy (2013). An Exploration of the Effects of the Servicescape on Customer and Employee Responses in a Grocery Retail ContextKeele Management School, Keele University, UK $\uparrow$ College of Business, Dublin Institute of Technology, Aungier Street, Dublin 2

Tse D.K., and Wilton P.C., (1988). Expectation as a comparison standard in measuring service quality: An assessment of a reassessment. Journal of Marketing. Vol. 58. pp. 132-139.

Turley, L., \& Milliman, R. (2000). Atmospheric effects on shopping behavior: A review of the experimental evidence. Journal of Business Research. Vol. 49. 193-211.

Tumbel Altje L., (2010). Pengaruh Kebanggaan, Kepercayaan, Kualitas Layanan dan Nilai Konsumen Terhadap Kepuasan dan Perilaku Membeli Ulang Wanita Karir Pada Pasar Swalayan Di Manado. Disertasi. Universitas Hasanuddin-Makassar.

Vanessa Gaffar (2007). Customer Relationship Management and Marketing Public Relations. Bandung-Alfabeta

Véronique Aubert-Gamet, Servicescapes: From Modern Non-Places to Postmodern Common Places. Journal of Business Research. Vol. 44. pp. 37-45 (1999) ã 1998 Elsevier Science Inc. All rights reserved. ISSN 0148-2963/99/\$-see front matter 655 Avenue of the Americas, New York, NY 10010 PII S0148-2963(97)00176-8.

Véronique Aubert-Gamet, (1996). Twisting servicescapes: diversion of the physical environment in a re-appropriation process. International Journal of Service Industry Management. Vol. 8 No. 1.pp. 26-41. (C) MCB University Press, 0956-4233.

Wakefield, L.K. and Blodgett G.J. (1996). "The effect of the servicescape on customer behavior intentions in leisure service setting”. Journal of Services Marketing. Vol. 10, No. 6. pp. 45-61.

Ward, J.C., Bitner, M.J., and Barnes, J. (1992). "Measuring the prototypicality and meaning of retail environments". Journal of Retailing. Vol. 68, Pp. 194-220.

Westbrook, R.A., and Oliver R.L., (1991). The dimensionability of consumption emotional pattens and customer satisfaction. Journal of Consumer. Vol. 18 June, pp. 84-91.

Wolfinbarger Mary, Mary C. Gilly (2003). eTailQ: dimensionalizing, measuring and predicting etail quality. Journal of Retailing. Vol. 79. pp. 183-198.

Yoon, M.H., and Suh J. (2003). "Organizational citizenship behaviors and service quality as external effectiveness of contact employee”. Journal of Business Research. Vol. 56. pp. 597-611.

Xiaoyu Chen, Steve Goodman, Justin Cohen, Johan Bruwer (tt). Wine tourists' loyalty intentions: Toward an integrated behaviour model.johan.bruwer@unisa.edu.au

Yangyang Gao (2016). The impact of guest room environment on customer perception: The case of economy hotels in guizhou province in china. Thesis - Faculty of California State Polytechnic University, Pomona.

Zeitham, V.A., and Bitner Mary Jo. (2000). Service marketing: integrating customer focus across the firm. Second Edition, USA, Boston: Irwin McGraw-Hill. Inc.

Zeitham, V.A., Berry L.L. and Parasuraman A. (1996). "The behavioral consequences of service quality". Journal of Marketing. Vol. 60. April, pp. 31-46. 
Zeitham, V.A., (1988). "Communication and control processes in the delivery of service quality". Journal of Marketing. Vol. 52. No. 2. pp. 35-48.

Zikmund W.G. (1994). Business Research Methods. International Edition. USA: The Dryden Press. 